Esta revista forma parte del acervo de la Biblioteca Jurídica Virtual del Instituto de Investigaciones Jurídicas de la UNAM

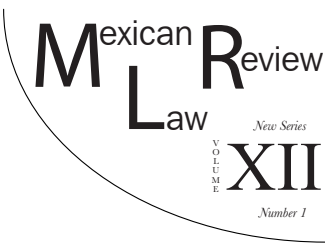

\title{
THE CRIMINAL LIABILITY OF CORPORATIONS: A STEP FORWARD IN THE IMPLEMENTATION OF THE UNITED NATIONS GUIDING PRINCIPLES ON BUSINESS AND HUMAN RIGHTS?
}

\author{
Alejandro SÁNchez González*
}

\begin{abstract}
The UN Guiding Principles on Business and Human Rights (UNGP) marked the end of a long journey towards regulating corporate conduct on this issue. However, they were conceived only as a focal point to guide public, corporate and civil governance towards the respect and protection of human rights. For this reason, the UNGP function as a common platform on which new rules and strategies should be developed. In this sense, as an element of public governance, Mexico adopted the criminal liability of corporations (CLC), which entered into force in 2016, along with the accusatory criminal justice system. Thus, since one of the purposes of criminal law is the subsidiary protection of legal assets - most of which have an underlying fundamental right -, the purpose of this article is to determine whether or not Mexico's adoption of the CLC enhances the implementation of the UNGP, and if so, to evaluate its scope and limitations. After scrutinizing the UNGP in light of the regulation of the CLC in Mexico, the author argues that, although its performance can be optimized in many ways, the CLC plays an essential role in the area of business and human rights, not only for its direct contributions, but also for the interaction it generates with corporate and civil governance.
\end{abstract}

KEYwORDS: Business and human rights, corporate criminal liability, human rights due diligence, criminal compliance.

RESUMEN: Los principios rectores de la ONU sobre las empresas y los derechos humanos (PR) marcaron el final de un largo camino hacia la regulación de la conducta de las corporaciones en relación con esta materia. No obstante, los mismos fueron concebidos únicamente como un punto focal tendiente a orien-

* M.A. in Human Rights, Instituto de Estudios Superiores en Derecho Penal, Mexico. LL.B. Universidad Iberoamericana, Mexico. Lecturer of Criminal Law and Criminal Procedure Law at the Universidad Iberoamericana, Mexico. LLM student at The University of Melbourne, Australia.Email: alejandros@student.unimelb.edu.au. 
Esta revista forma parte del acervo de la Biblioteca Jurídica Virtual del Instituto de Investigaciones Jurídicas de la UNAM

tar las gobernanzas pública, corporativa y civil hacia el respeto y protección de los derechos humanos. Por ello, los PR constituyen una plataforma común sobre la cual nuevas reglas y estrategias de regulación deben desarrollarse. En este sentido, como un elemento de la gobernanza pública, México adoptó la responsabilidad penal de las empresas (RPE), la cual entró en vigor en 2016, junto con el sistema acusatorio de justicia penal. En este sentido, si uno de los fines del derecho penal es la protección subsidiaria de bienes jurídicos - en la mayoría de los cuales subyace un derecho fundamental - el propósito de este articulo es determinar si la adopción en México de la RPE constituye un avance en la implementación de los $P R$, y en su caso, evaluar cuáles son sus alcances y limitaciones. Después de escrutar los PR a la luz de la regulación de la RPE, el autor sostiene que, aunque existen diversas maneras de optimizar su contribución, la RPE desempeña una función esencial en el campo de las empresas y los derechos humanos, no solo por sus aportaciones directas, sino también por las relaciones de refuerzo que entabla con las gobernanzas corporativa y civil.

Palabras Clave: Empresas y derechos humanos, responsabilidad penal de las empresas, debida diligencia en derechos humanos, cumplimiento penal empresarial.

\section{Table of Contents}

I. INTRODUCTION

II. Business And Human Rights ..................................................... 94

1. Background

A. The Need for Regulating the Impact of Business on Human Rights

B. Attempts at Regulation

2. The UN Guiding Principles

on Business and Human Rights

A. Development of the UNGP ............................................ 96

B. Protect, Respect and Remedy Framework ........................... 97

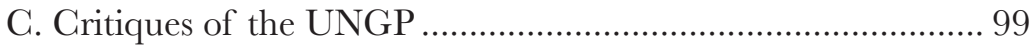

D. Building upon the UNGP ................................................. 100

III. Criminal Law in Relation to Business AND Human Rights

1. Criminal Law as a Protector of Human Rights

2. Mexico's Regime for Criminal Liability of Corporations
A. Background
B. Accusation Model
C. Criminal Compliance Program
D. Crimes that can be Attributed to Legal Persons 
E. Punishment and Alternative Dispute Resolution

Mechanisms

IV. The CLC: A Step Forward in the Implementation OF THE UNGP?

1. Contribution to the State Duty to Protect

A. Guiding Principle 1 ...................................................... 106

B. Guiding Principle 2 ....................................................... 106

C. Guiding Principle 3 ...................................................... 107

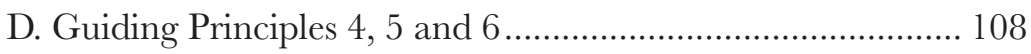

E. Guiding Principle 7 ....................................................... 109

F. Guiding Principles 8, 9 and 10...................................... 110

2. Contribution to the Corporate Responsibility to Respect ......... 110

A. Guiding Principle 11 ..................................................... 110

B. Guiding Principle 12 ....................................................... 111

C. Guiding Principle 13 ...................................................... 117

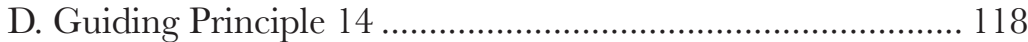

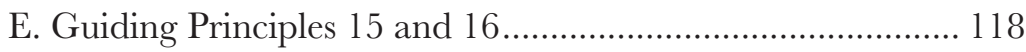

F. Guiding Principles 17, 18, 19, 20 and 21 ........................ 119

3. Access to Remedy ............................................................. 120

A. Guiding Principles 25, 26 and 27 ................................... 120

B. Guiding Principles 28, 29, 30 and 31 ............................. 121

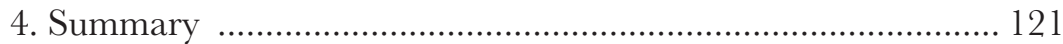

V. Gonclusion..................................................................... 124

\section{INTRODUCTION}

The UN Guiding Principles on Business and Human Rights (UNGP) marked the end of a long journey towards regulating the conduct of corporations regarding this issue. However, the UNGP were conceived only as a focal point that tends to guide public, corporate and civil governance to the promotion and protection of human rights. Thus, these three systems of regulation must interact in a network-like fashion to enhance their strengths, shore up each other's weaknesses and face the challenges that a globalized market entail. For this reason, the UNGP work as a common platform on which new rules and strategies can be built upon.

In this sense, as an element of public governance, Mexico adopted the criminal liability of corporations (CLG), which entered into force in 2016, along with an accusatorial criminal justice system. Thereby, since one of the purposes of criminal law is the subsidiary protection of legal assets - in most of which a fundamental right underlies - , the purpose of this article is to 
determine whether or not Mexico's adoption of the CLC furthers the implementation of the UNGP, and if so, to evaluate its scope and limitations.

To this end, Chapter II will examine the regulatory framework implemented by the UNGP. In Chapter III, I will address the role of criminal law as a protector of human rights and how it can be enforced against corporations in Mexico. Finally, in Chapter IV, I will scrutinize the UNGP in correlation with the CLC. This will lead to the conclusion that, although its performance can be optimized in many ways, the CLC plays an essential function in the area of business and human rights, not only for its direct contributions, but also for the interaction it generates with the corporate and civil governance.

\section{Business AND Human Rights}

To contextualize the main topic of the essay, this chapter will first address the need for regulating the impact of business on human rights and the initiatives that have been presented for this purpose. Then, I will examine the content and structure of the regulatory framework proposed by the UNGP, as well as the main critiques against it. Finally, I will explore ways in which the shortcomings of the framework can be overcome by using the UNGP as a common platform from which other developments can depart.

\section{Background}

\section{A. The Need for Regulating the Impact of Business on Human Rights}

Traditionally, human rights were conceived as barriers against the abusive exercise of public power. ${ }^{1}$ Consequently, the human rights regime was designed in a unidimensional way that considered states as the only duty bearers. $^{2}$ However, since power should entail responsibility, the law must limit and discipline any kind of power, not only governmental. ${ }^{3}$

In this sense, we must acknowledge that in the past decades private corporations have gained significant power and authority, which can be wielded with relative autonomy. ${ }^{4}$ Companies support politicians and lobby institu-

1 David Weissbrodt \& Muria Kruger, Human Rights Responsibilities of Business as NonState Actors, in Non-State Actors and Human Rights 315 (Philip Alston, Oxford University Press, 2005).

2 Philip Alston, The Not-a-Cat Syndrome: Can the International Human Rights Regime Accommodate Non-State Actors?, in Non-State Actors and Human Rights 3 (Philip Alston, Oxford University Press, 2005).

3 Weissbrodt \& Kruger, supra note 1.

4 See John Gerard Ruggie, Multinationals as Global Institution: Power, Authority and Relative Autonomy, in Regulation and Governance (David Levi-Faur, Wiley Editing Services, 2017). 
tions to achieve their goals, request structural reforms in countries as a condition for investment and, contribute to shaping social expectations through marketing campaigns. As well, catastrophes like the one occurred in 1984 in Bhopal, India - in which three thousand people died, and tens of thousands more were injured due to a gas leak at a pesticide plant-, remind us of the risks that commercial activities pose to workers, communities and the environment. ${ }^{5}$ Therefore, the regulatory framework must be adapted to this new context and address the potential impact of business on human rights.

\section{B. Attempts at Regulation}

The Universal Declaration of Human Rights (UDHR) is addressed to every individual and every organ of society, including corporations. ${ }^{6}$ For this reason, there have been many initiatives to regulate corporate responsibility regarding human rights.

A first attempt took place in the 1970s when the UN developed the Draft Code of Conduct on Transnational Corporations, which was never officially implemented. ${ }^{7}$ In that same decade, the Organization for Economic Co-operation and Development (OECD) adopted the Guidelines for Multinational Enterprises, and the International Labor Organization (ILO) put into effect the Tripartite Declaration of Principles concerning Multinational Enterprises, which was later complemented with the Declaration of Fundamental Principles and Rights at Work in $1998 .^{8}$

In 1999, the UN developed the Global Compact as a voluntary proposal to encourage companies to embrace ten principles concerning environmental protection, anti-corruption strategies and the respect of international human rights. ${ }^{9}$ Nevertheless, even when this initiative has attracted considerable corporate support, it has been criticized due to its vagueness and weakness to motivate companies to improve their performance in these areas. ${ }^{10}$

Consequently, in 1999, the UN designated a working group to draft a code of conduct for corporations regarding human rights. The first issues to arise were to determine whether the regulation should be voluntary or mandatory, and whether it should apply to all business enterprises or only transnational

5 See Surya Deva, Bhopal: The Saga Continues, in Business and Human Rights: From Principles to Practice 22 (Dorothée Baumann-Pauly \& Justine Nolan, Routledge, 2016).

${ }^{6}$ Justine Nolan, Mapping the Movement: The Business and Human Rights Regulatory Framework, in Business and Human Rights: From Principles to Practice 27 (Dorothée Baumann-Pauly \& Justine Nolan, Routledge, 2016).

7 Weissbrodt \& Kruger, supra note 1, at 318.

8 Id. at 319.

9 United Nations, Global Compact (2018) available at wrew.unglobalcompact.org.

10 Philip Alston \& Ryan Goodman, International Human Rights 1468 (Oxford University Press, 2013). 
corporations. ${ }^{11}$ In the end, the working group proposed the Norms on the Responsibilities of Transnational Corporations and other Business Enterprises with Regard to Human Rights (the Norms), as a mandatory standard to regulate all kinds of companies. ${ }^{12}$ Even though many NGOs welcomed the Norms, most developed countries considered them unnecessary or overreaching. ${ }^{13}$ Thus, in 2004, the UN affirmed that these norms had no legal standing. ${ }^{14}$

Therefore, in 2005, John Gerard Ruggie was appointed as Special Representative of the UN Secretary-General (SRSG) and given the task to identify and clarify standards and best practices in the area of business and human rights. ${ }^{15}$ By the end of his assignment in 2011, and going beyond the initial mandate, he proposed the UNGP, which were unanimously supported by the UN Human Rights Council. ${ }^{16}$ The development of the UNGP and their regulatory framework will be analyzed in the following section.

\section{The UN Guiding Principles on Business and Human Rights}

\section{A. Development of the UNGP}

During the last decades, transnational business enterprises have experienced exponential growth and redefined their role in the globalized society. ${ }^{17}$ Nowadays, there are more multinational corporations than ever before, and their traditional integrated composition has been transformed into a networklike structure, characterized by worldwide supply chains and joint ventures. ${ }^{18}$ Thus, the task undertaken by the SRSG was anything but simple: to identify the most suitable way of regulating the impact of business on human rights within this complex backdrop.

After the experience of the Norms, the SRSG realized that, while human rights advocates preferred mandatory initiatives, such as a binding international treaty, the business community was in favor of a hybrid alternative,

11 Weissbrodt \& Kruger, supra note 1, at 322.

12 Id.

13 Alston \& Goodman, supra note 10, at 1477.

14 Id.

15 John Gerard Ruggie, Just Business: Multinational Gorporations and Human Rights xi (Norton \& Company, 2013).

16 Id.

17 Justine Nolan, Business and Human Rights in Context, in Business and Human Rights: From Principles to Practice 2 (Dorothée Baumann-Pauly \& Justine Nolan, Routledge, 2016).

18 Richard Locke, We live in a World of Global Supply Chains, in Business and Human Rights: From Principles to Practice 299 (Dorothée Baumann-Pauly \& Justine Nolan, Routledge, 2016). 
which included compliance with domestic law and the implementation of voluntary measures of self-regulation. ${ }^{19}$ Nevertheless, the SRSG considered it necessary to move beyond the mandatory-voluntary discussion, and find middle ground on which cumulative progress could be achieved. ${ }^{20}$ This approach, which he called "principled pragmatism", intended to optimize the promotion and protection of human rights related to business through practical measures that were capable of transforming the daily situation of people. ${ }^{21}$

To this effect, the SRSG found that the conduct of corporations was affected by three different types of regulation. ${ }^{22}$ First, public governance, comprised of international and domestic law and policy. ${ }^{23}$ Second, corporate governance, integrated by institutional designs and management systems. ${ }^{24}$ And third, civil governance, represented by expectations and social pressure against corporations. ${ }^{25}$ Consequently, to effectively improve corporate behavior in regards to human rights, it was necessary to develop a common platform upon which these three systems of regulation could enhance their strengths and compensate their weaknesses. ${ }^{26}$ With this in mind, the SRSG drew up the UNGP as the focal point needed to guide public, corporate and civil governance towards the same goal: the protection and respect of human rights. ${ }^{27}$ The regulatory framework presented in the UNGP will be studied in the next section.

\section{B. Protect, Respect and Remedy Framework}

The UNGP regulatory framework is underpinned with three pillars identified by the verbs protect, respect and remedy. ${ }^{28}$ In this segment, I will only outline the general features since an in-depth analysis of each of the UNGP will be provided in chapter IV of this essay.

The first pillar, the obligation to protect, is aimed at States and tends to guide public governance towards the protection of human rights from corporate abuse. For this purpose, States have to adopt effective policies,

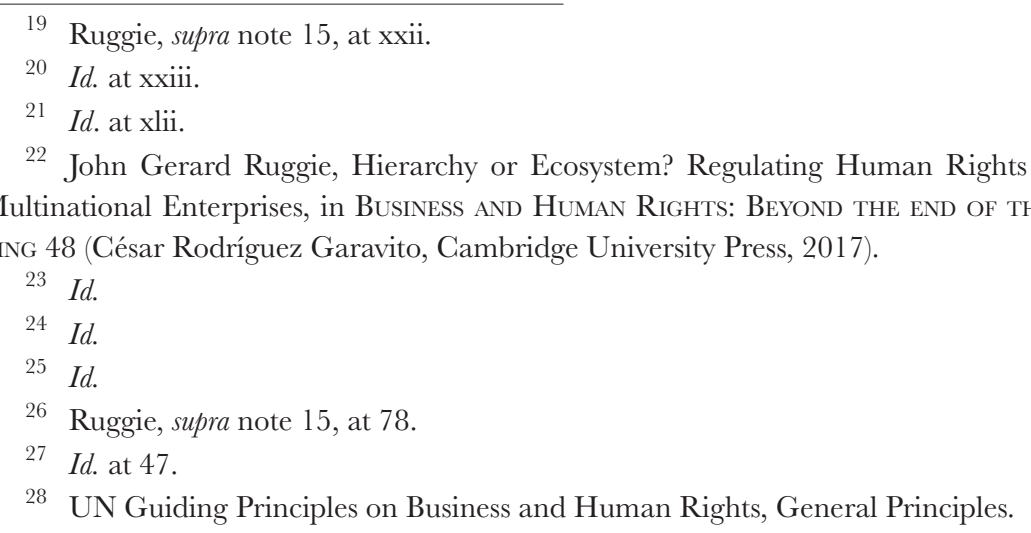


legislation and regulations to prevent, investigate, punish and redress any such abuse. ${ }^{29}$

The second pillar, the responsibility to respect, is directed at all types of corporations, regardless of their size, sector or operational context. ${ }^{30}$ It aims to expand corporate governance so it can embrace the respect for human rights by avoiding to cause harm to others and addressing any adverse effect they might have. ${ }^{31}$ Thus, every company should develop a human rights due diligence process to identify the potential risks its commercial activity may pose and to adopt the necessary measures to mitigate them. ${ }^{32}$

Finally, the purpose of the third pillar is to provide effective remedy to victims of human rights violations. To this end, States have to punish and redress any corporate violation of human rights through judicial, legislative, administrative or any other appropriate means. ${ }^{33}$ As well, corporations must implement and participate in remedial mechanisms, even in the case that the State is unwilling or unable to respond to a given abuse. ${ }^{34}$ Consequently, the procedures to provide a remedy to the victims can be State-based judicial (civil or criminal justice), State-based non-judicial (administrative process or conciliation) and non-State-based (agreements with victims, mutually accepted mediation, among others). ${ }^{35}$

Taking into account that three different systems of regulation affect the conduct of business enterprises (public, corporate and civil governance), the UNGP framework follows an experimentalist design, which is characterized by the open participation of a variety of actors and a network-like structure, rather than a rigid, vertical hierarchy between stakeholders. ${ }^{36}$ The SRSG considered that experimentalist governance was the adequate approach to govern the conduct of corporations because, in his view, other traditional, integrated or top-down models of governance have limited utility when dealing with current global challenges. ${ }^{37}$ Therefore, if corporations are growing exponentially and operating in a network-like fashion, regulation has to be dynamic and flexible enough to keep pace even in the form of soft-law. This SRSG's decision did not go unnoticed by many human rights professionals and scholars, who reacted to the UNGP. The principal points of criticism will be summarized in the following section.

29 Id. at Art. 1.

30 Id. at Art. 14.

31 Id. at Art. 11.

32 Id. at Art. 15.

33 Id. at Art. 26.

34 Id. at Art. 29.

35 Ruggie, supra note 15, at 102.

36 Gráinne de Búrca, Robert O. Keohane and Charles Sabel, New Modes of Pluralist Global Governance, 45(1) N.Y.U. J. Int'L L. \& Pol. 723, 738 (2013).

37 Ruggie, supra note 22, at 49. 


\section{Critiques of the UNGP}

The main criticism against the UNGP is that they constitute a voluntary initiative with no binding effect and, consequently, misrepresent the proper steps required to regulate corporations in regards to human rights. ${ }^{38}$ For many scholars, the respect for human rights cannot be conditioned to the goodwill of corporations because, as Milton Friedman stated, companies are only concerned with making as much money as possible. ${ }^{39}$ Therefore, professionals that support this idea are in favor of negotiating and adopting a legally binding treaty on business and human rights, or even the creation of an international court to settle claims against corporations for violating fundamental rights. ${ }^{40}$

In response to this, the SRSG affirmed that the treaty route is unsuitable because, since the topic of business and human rights is still new for governments, the negotiation of a treaty would take a long time and human rights would have to be safeguarded by other means in the meantime. ${ }^{41}$ Moreover, the SRSG acknowledged that existing human rights treaties have not been entirely effective. ${ }^{42}$ Conversely, the committees currently in place cannot fulfill their duties even though they might only monitor compliance with a single set of rights. ${ }^{43}$ Therefore, it would be unrealistic for these committees to cover a broader range of rights in a never-ending number of corporations. ${ }^{44}$

A second criticism is that UNGP do not allow enough civil participation. ${ }^{45}$ Consequently, if civil governance is not highly developed, ${ }^{46}$ the regulatory framework will be ineffective to shift the power dynamics and compensate for the asymmetrical social relations that cause human rights abuses. ${ }^{47}$

38 Christine Parker \& John Howe, Ruggie's Diplomatic Project and its Missing Regulatory Infrastructure, in The UN Guiding Principles on Business and Human Rights 273 (Radu Mares, Martinus Nijhoff Publishers 2012).

39 See Milton Friedman, The Social Responsibility of Business is to Increase its Profits, N.Y. Times Magazine, September 11, 1970.

40 See Surya Deva \& David Bilchitz, Building a Treaty on Business and Human Rights: Context and Contours (Cambridge University Press, 2017).

41 Ruggie, supra note 19, at 57.

42 Id. at 60.

43 Id. at 64.

44 Id.

45 See Tara J. Melish, Putting Human Rights Back into the UNGP on Business and Human Rights: Shifting Frames and Embedding Participation Rights, in Business and Human Rights: Beyond the end of the Beginning (César Rodríguez Garavito, Cambridge University Press, 2017).

46 César Rodríguez-Garavito, Business and Human Rights: Beyond the End of the Beginning, in Business and Human Rights: Beyond the end of the Beginning 41 (César Rodríguez Garavito, Cambridge University Press, 2017).

47 Chris Jochnick, Shifting Power on Business and Human Rights: States, Corporations 
In this respect, the SRSG replied that he conceptualized UNGP bearing in mind the importance of civil society participation, which plays a vital role in the experimentalist approach. ${ }^{48}$ Furthermore, he said that UNGP constitute an effective tool for advocacy that can be used by NGOs and workers associations. $^{49}$

The above criticism is weighty and persuasive. However, we should remember that even when UNGP marked the end of a long journey towards regulating business and human rights, they are just the starting point on which further developments can be constructed. Therefore, the voluntary nature of UNGP and the limited role of civil society can be strengthened by building upon this common platform, as I will illustrate in the next section.

\section{Building upon UNGP}

The UNGP have two different dimensions. ${ }^{50}$ The static dimension is shaped by their foundational and operational standards. ${ }^{51}$ However, the dynamic dimension refers to their ability to foster the creation of new norms and practices that, when pulling in the same direction, can improve corporate compliance with human rights. ${ }^{52}$ Therefore, UNGP must be understood as ongoing processes rather than a fixed document. ${ }^{53}$

In this sense, the effectiveness of UNGP must be improved through the strategic development of public, corporate and civil governance. If these three systems operate together, they can generate cumulative progress and contribute to the protection of human rights. ${ }^{54}$

As César Rodríguez-Garavito asserts, the field of human rights is expanding its boundaries with the incorporation of new rights, different duty-bearers and rights-holders, as well as innovative types of regulation and adjudication. ${ }^{55}$ These novel elements coexist in a way that is both horizontal and interconnected, resembling the structure of an ecosystem. ${ }^{56}$ Consequently, the individual contribution of each component and the reinforcing or symbiotic

and Civil Society in Global Governance, in Business and Human Rights: Beyond the END of the Beginning (César Rodríguez Garavito, Cambridge University Press, 2017).

48 Ruggie, supra note 22, at 52.

49 Id. at 53.

50 Rodríguez-Garavito, supra note 46, at 11.

$51 \mathrm{Id}$.

52 Id.

53 Ruggie, supra note 22, at 47.

54 Rodríguez-Garavito, supra note 46, at 11.

55 César Rodríguez-Garavito, The Future of Human Rights, from Gatekeeping to Symbiosis, 20 SUR International Journal on Human Rights 499, 505 (2014).

56 Id. 
relations each can build with the others are essential to the effective protection of the people. ${ }^{57}$

Having analyzed the background, context and current regulation of business and human rights, the following sections discuss whether Mexico's recent adoption of the criminal liability of corporations, as part of public governance, advances the implementation of UNGP, and if it builds mutually reinforcing relationships with corporate and civil governance, as encouraged by the dynamic dimension of UNGP.

\section{Criminal LaW in Relation to Business and Human Rights}

In this chapter, I will address the role of criminal law as a protector of human rights. I will also examine the enforcement of the criminal liability of corporations (CLC), as it is regulated in Mexico. Since the main topic of this essay falls within the field of business and human rights, explanations on the CLC will be brief.

\section{Criminal Law as a Protector of Human Rights}

The Political Constitution of the United Mexican States confers authority to the Congress to determine criminal offenses against the Federation and their corresponding penalties. ${ }^{58}$ However, this does not imply that the legislators can punish any type of behavior, since their punitive power is limited by the objectives of criminal law. ${ }^{59}$

For this reason, since the primary purpose of criminal law is to safeguard legally protected assets, the only conducts that can be considered crimes are those that can harm said assets or put them in actual danger. ${ }^{60}$ Nevertheless, the defense of legally protected assets is not only undertaken by criminal law, but also by the entire legal system. ${ }^{61}$ Therefore, since criminal repression is the most violent response of the State against an individual, it should only punish the most severe attacks against the assets deemed most essential for society. ${ }^{62}$ Less harmful behaviors should be regulated by other branches of law such as civil

\footnotetext{
$57 \quad I d$.

58 Constitución Política de los Estados Unidos Mexicanos [C.P.E.U.M.] [Political Constitution of the United States of Mexico], as amended, article 73 XXI b), Diario Oficial de la Federación [D.O.], February 5, 1917, (Mex.).

59 Claus Roxin, Derecho Penal Parte General [Criminal Law General Part] 51 (Civitas, 1997).

$60 I d$.

${ }^{61} I d$. at 65.

$62 I d$.
} 
or administrative law. ${ }^{63}$ This is why criminal law is considered the last resort of the social policy. ${ }^{64}$

In this sense, legally protected assets can be defined as given circumstances or aims that are useful to the free development of the individual. ${ }^{65}$ Consequently, legally protected assets are, for example, life, physical integrity, liberty, public health or the environment, without which the development of the individual would terminate or be severely compromised. ${ }^{66}$

At this point, the object of protection of criminal law coincides with the natural concept of human rights. ${ }^{67}$ Nonetheless, we should emphasize that criminal law only punishes serious offenses to legally protected assets, as described in law, while human rights violations can be caused by many other behaviors that may not be considered crimes.

This is not the place to delve further into this topic. However, Chapter IV of this essay provides a chart of the internationally recognized human rights and the crimes that directly go against them. Let us now examine how criminal law can be enforced, so it can regulate the impact that business enterprises have on human rights.

\section{Mexico's Regime for Criminal Liability of Corporations}

On June 18, 2016, Mexico's National Code of Criminal Procedures (NCGP) was enacted. ${ }^{68}$ Besides the implementation of an accusatorial criminal justice system, the NCGP introduced a special procedure to prosecute legal persons; ${ }^{69}$ that is, any collective organization composed of individuals, which operates as a separate entity, such as corporations. ${ }^{70}$ In this section, I will address the key features of the CLC.

\section{A. Background}

Historically, the criminal system of Mexico considered that only natural persons could commit crimes. Nevertheless, since commercial activity was

63 Id.

64 Id.

65 Id. at 54 .

66 Juan Bustos \& Hernán Hormazábal, Lecciones de Derecho Penal 56 [Lessons of Criminal Law] (Trotta, 1997).

67 Marie Bénédicte Dembour, What are Human Rights? Four Schools of Thought, 32 Human Rights Quarterly 1, 2 (2010).

68 Código Nacional de Procedimientos Penales [C.N.P.P.] [National Code of Criminal Procedures], as amended, Diario Oficial de la Federación [D.O.], March 5, 2014, (Mex.).

69 Id. at Arts. 421-425.

70 Luis David Goaña Be, La Responsabilidad Penal de las Empresas 11 [The Criminal Liability of Corporations] (INACIPE, 2017). 
increasingly generating risks that oftentimes led to the commission of crimes, Congress drafted the CLC as a mechanism to allow the indictment of all legal persons, excluding State-owned or operated institutions. ${ }^{71}$

In doing so, legislators aimed to modernize the regulations, since the dissipation of liability between the holding and its subsidiaries, the complex distribution of tasks within the organization, and interstate and transnational commercial activities were hindering the enforcement of criminal law. ${ }^{72}$ Taking these challenges into account, Congress produced the accusation model to be analyzed next.

\section{B. Accusation Model}

Article 421 of the NCCP establishes a direct and autonomous accusation model against legal persons. ${ }^{73}$ This means that legal persons can be liable for the commission of a crime, regardless of the responsibility of the natural person directly involved in the facts. ${ }^{74}$ Moreover, this provision establishes two requirements for the accusation of a legal person: (i) that the crime be committed in its name, for its benefit or through means provided by it, (ii) and that, in addition, a non-compliance with the due control in the organization be proven. ${ }^{75}$

The second condition implies that, if the legal person demonstrates due control in the organization; that is, the implementation of strategies, protocols and policies to identify risks and prevent crimes from being committed, its criminal responsibility would be ruled out or, at least, attenuated. This is because a natural person that eludes due diligence controls to commit a crime is acting on his or her own and not on behalf of the corporation. ${ }^{76}$ Consequently, corporations should adopt a compliance program to manage and mitigate criminal risks as an essential measure to avoid criminal liability. ${ }^{77}$ The requirements of such a program will be analyzed hereunder.

71 Código Nacional de Procedimientos Penales [C.N.P.P.] [National Code of Criminal Procedures], as amended, Art. 421, Diario Oficial de la Federación [D.O.], March 5, 2014, (Mex.).

72 Coaña, supra note 70 , at 3.

73 Código Nacional de Procedimientos Penales [C.N.P.P.] [National Code of Criminal Procedures], as amended, Art. 421, Diario Oficial de la Federación [D.O.], March 5, 2014, (Mex.).

74 Coaña, supra note 70 , at 15.

75 Código Nacional de Procedimientos Penales [C.N.P.P.] [National Code of Criminal Procedures], as amended, Art. 421, Diario Oficial de la Federación [D.O.], March 5, 2014, (Mex.).

76 Coaña, supra note 70 , at 16.

77 Miguel Ontiveros Alonso, ¿Para qué sirve el compliance en materia penal? [ What is the purpose of a criminal compliance program?], in El Código Nacional de Procedimientos Penales. Estudios 146 [Studies on the National Code of Criminal Procedures] (Sergio García Ramírez, IIJ-UNAM, 2015). 
Esta revista forma parte del acervo de la Biblioteca Jurídica Virtual del Instituto de Investigaciones Jurídicas de la UNAM

\section{Criminal Compliance Program}

A criminal compliance program is composed of a broad assortment of measures implemented by an organization to prevent the commission of crimes. ${ }^{78}$ It expresses the corporate commitment to adopt a culture of legality. ${ }^{79}$ However, in Mexico there is a legal void on this topic because, even when the NCCP assumes the adoption of such program to rule out or attenuate the CLC, there is no further provision that explains it requirements.

Therefore, to fill this legal gap, it is necessary to dip into external materials, such as comparative law or standardization norms like ISO 19600 on compliance management systems, ISO 26000 on social responsibility, or even the UNGP for they provide recommendations on this issue. ${ }^{80}$ Thus, a criminal compliance program should consider, at least, the following aspects: (i) the identification of criminal risks, (ii) the adoption and implementation of protocols and policies to mitigate such risks, (ii) corporate commitment to prevent the commission of crimes, (iii) the allocation of financial resources and the creation of a body to run the program, (iv) the creation of internal disciplinary and grievance mechanisms, (v) internal and external communication of the progress made and (vi) the continuous program revision. ${ }^{81}$

There are still several areas of the CLC that need to be complemented by Congress and these will be pointed out in Chapter IV of this essay. However, this has not been an obstacle for some Mexican states to also adopt the CLC at the local level and develop more comprehensive regulations, as in the case of the state of Quintana Roo, ${ }^{82}$ to which I will return later. For now, let us continue with the analysis of the CLC as regulated by the NCGP.

\section{Crimes that can be Attributed to Legal Persons}

One interesting feature of the CLC is that legal persons cannot be prosecuted for the commission of just any crime, but only those listed in the Article 11 bis of the Federal Criminal Code, ${ }^{83}$ which are mainly related to what is called economic criminal law. ${ }^{84}$ It is not my intention to discuss why legislators only included those offenses in the CLC. However, as I will argue in

$78 \quad I d$.

79 Id.

80 United Nations Guiding Principles on Business and Human Rights Arts. 19-21.

81 Coaña, supra note 70 , at 22.

82 See Código Penal para el Estado de Quintana Roo [C.P.Q.R.] [Criminal Code for the State of Quintana Roo] as amended, Articles 18-18 nonies, Periódico Oficial del Estado de Quintana Roo [P.O.Q.R.], March 29, 1991, (Quintana Roo, Mex.).

83 Código Penal Federal [C.P.F.] [Federal Criminal Code], as amended, Article 11 bis, Diario Oficial de la Federación [D.O.], August 14, 1931, (Mex.).

84 Coaña, supra note 70 , at 27. 
Chapter IV, this catalog should be considerably expanded to optimize the contribution of criminal law in the protection of human rights.

\section{E. Punishment and Alternative Dispute Resolution Mechanisms}

Since legal persons are inventions and cannot be deprived of their liberty, it was necessary to conceive sanctions that were suitable to their nature. Currently, Article 422 of the NCCP establishes the following: (i) fines, (ii) comprehensive reparation of damages, (iii) confiscation of assets, (iv) the publication of a sentence ( $\mathrm{v}$ ) and the dissolution of the organization. ${ }^{85}$

However, a criminal conviction can also entail non-legal consequences, such as a tarnished image of the corporation, decreased value of the company and its shares, a loss of clients and suppliers, and limitations for obtaining credit, among others. ${ }^{86}$ In this sense, the CLC also enables alternative dispute resolution mechanisms, so that, by compensating the victims, corporations can avoid these undesirable effects. ${ }^{87}$

Having studied the role of criminal law as a subsidiary protector of human rights and its enforcement against legal persons, let us analyze the contribution of the CLC to business and human rights.

\section{The CLC: A Step Forward \\ IN THE IMPLEMENTATION OF THE UNGP?}

So far, we have explored the current situation of business and human rights, as well as the purpose, content and scope of the CLC as it has recently been implemented in Mexico. We will now delve into the central issue of this article and determine to what extent the CLC contributes to regulate the conduct of corporations in accordance with the UNGP. To this effect, this chapter will scrutinize each of the foundational and operational standards to determine up to what point the GLC can fulfil them.

\section{Contribution to the State Duty to Protect}

The State duty to protect human rights is stated in the first part of the framework and comprises UNGP 1 to 10.

85 Código Nacional de Procedimientos Penales [C.N.P.P.] [National Code of Criminal Procedures], as amended, Art. 422, Diario Oficial de la Federación [D.O.], March 5, 2014, (Mex.).

86 Coaña, supra note 70 , at 30 .

87 Código Nacional de Procedimientos Penales [C.N.P.P.] [National Code of Criminal Procedures], as amended, Art. 424, Diario Oficial de la Federación [D.O.], March 5, 2014, (Mex.). 


\section{A. Guiding Principle 1}

This principle establishes the State duty to protect against human rights violations by third parties, including corporations, within their territory and/ or jurisdiction. ${ }^{88}$ To this effect, States must take appropriate steps to prevent, investigate, punish and redress human rights abuse, through effective policies, legislation, regulations and adjudication. ${ }^{89}$

Mexico has partially fulfilled these obligations by adopting the CLC, since it is a legislative measure that aims to protect human rights, in the form of legally protected assets, from potentially harmful activities carried out by business enterprises. Furthermore, as a national law, it applies to all Mexican territory at both federal and local levels. Hence, the enactment of the CLC represents an appropriate step towards preventing, investigating, punishing and redressing human rights abuses by corporations.

However, compliance with this UNGP is incomplete because, according to Article 11 bis of the $\mathrm{FCG}^{90}$ the CLG is limited to specific crimes, which do not entirely encompass the broad array of human rights outlined in the International Bill of Human Rights and the ILO Declaration on Fundamental Principles and Rights at Work, as indicated in UNGP 12.

Therefore, the scope of protection of the CLC in Mexico should be extended, so it can cover all human rights violations applicable to criminal law. The discussion on the scope of defense provided by the CLC is found in the analysis of the UNGP 12, but let us continue with the following principle.

\section{B. Guiding Principle 2}

This principle provides that States must clearly lay down the expectation that all companies in their territory and jurisdiction are to respect human rights throughout their operations. ${ }^{91}$

In this regard, legislation is a suitable way of setting out social expectations since it is ultimately an instrument of communication. Consequently, to fully comply with this principle, among other measures, it is necessary for States to enact law that explicitly specify corporations' obligation to respect human rights. Currently, there is no such law in Mexico. However, the CLC helps to create the expectation that corporations should respect the human rights protected by criminal law. In this sense, due to the restricted catalog of crimes companies can held responsible for, the CLC only partially meets

\footnotetext{
88 United Nations Guiding Principles on Business and Human Rights Art. 1.

$89 I d$.

90 Código Penal Federal [C.P.F.] [Federal Criminal Code], as amended, Article 11 bis, Diario Oficial de la Federación [D.O.], August 14, 1931, (Mex.).

91 United Nations Guiding Principles on Business and Human Rights Article 1.
} 
with this UNGP. Nevertheless, as I will further argue, if this catalog were extended to other existing crimes, it could enhance the contribution of the CLG to this UNGP.

\section{Guiding Principle 3}

This principle refers to the State regulatory function and establishes four different obligations. ${ }^{92}$ First, to enforce laws that require corporations to respect human rights; second, to ensure that other laws and policies that govern corporations do not limit but promote respect for human rights; third, to provide guidance to companies on how to respect human rights in their operations; and fourth, to encourage business enterprises to communicate how they are addressing their impact on human rights. ${ }^{93}$

In connection with the first obligation, the GLC constitutes a legislative measure that clearly demands corporations to respect human rights. Article 421 of the NGCP states that legal persons shall be responsible for any crimes committed in their name, in their benefit or through the means that they provide, if it can be proven a lack of control in the organization. ${ }^{94}$ As analyzed in Chapter III, to prove proper control and, consequently, rule out their liability, corporations must demonstrate the existence of an effective compliance program, which includes the detection, prevention and mitigation of criminal risks. Consequently, the CLC indirectly contributes to this compliance since it requires companies to implement a criminal preventive program as part of their responsibility to respect human rights.

As regards the second obligation, the CLC has made no contribution because it is mainly related to corporate law. Nevertheless, the GLC can play an important role in the third and fourth obligations. Currently, neither the FCG nor the NCCP explain the mandatory features of a criminal compliance program. However, these provisions can be reformed to provide sufficient guidance on how to develop an efficient criminal compliance program, which can include the creation of channels to communicate the preventive measures implemented by the corporations. One example of this is found in the local legislation of the state of Quintana Roo, Mexico, which elaborates on the requirements of a criminal compliance program, including the identification of risks, the adoption of protocols and the allocation of financial resources for the prevention of crimes, the creation of a body in charge of the program implementation, the creation of internal grievance mechanisms, and the constant review and updating of the adopted programs. ${ }^{95}$ If this guidance on

92 Id. at Art. 3.

93 Id.

94 Código Nacional de Procedimientos Penales [C.N.P.P.] [National Code of Criminal Procedures], as amended, Art. 421, Diario Oficial de la Federación [D.O.], March 5, 2014, (Mex.).

95 See Código Penal para el Estado de Quintana Roo [C.P.Q.R.] [Criminal Code for the 
how corporations can respect human rights is provided at a local level, there is no obstacle for doing the same at the federal level.

\section{Guiding Principles 4, 5 and 6}

These guidelines are related to the State's responsibility when conducting commercial activities, licensing others to provide services with potential impact on human rights and hiring private corporations. ${ }^{96}$

Principle 4 establishes the obligation to protect against human rights abuses by corporations that are owned or controlled by the State. ${ }^{97}$ To this effect, the CLC has nothing to offer since, according to the second paragraph of Article 421 of the NCCP, State institutions cannot incur in criminal liability. ${ }^{98}$ It is understandable to safeguard the operation of official corporations because, to some extent, they perform public services. Therefore, the suspension of activities or the dissolution of the company would be undesirable for the State and possibly more harmful to society than the crime committed. However, this exemption should not be interpreted as if the official corporations were not required to implement a criminal compliance program. They might not be accountable for the crimes, but they still have the duty to prevent crimes from happening. For these reasons, non-criminal (administrative) measures would be more suitable to comply with this obligation.

Meanwhile, principle 5 provides that States must oversee the operations of companies that provide privatized services with a direct impact on human rights, such as water supply, electric energy, healthcare, and private security, among others. ${ }^{99}$ In this regard, since such corporations are not owned or controlled by the State, they can be criminally liable. Consequently, the CLC contributes to comply with this guideline because by monitoring company operations, the State is able to initiate a criminal procedure for the commission of a crime as an accountability mechanism.

In addition, principle 6 orders that States should promote respect for human rights by corporations with which they conduct commercial transactions. ${ }^{100}$ To this end, the CLC can play an important role since States are able to set the implementation of a criminal compliance program as an official requirement for public contracting.

\footnotetext{
State of Quintana Roo] as amended, Article quinquies, Periódico Oficial del Estado de Quintana Roo [P.O.Q.R.], March 29, 1991, (Quintana Roo, Mex.).

96 United Nations Guiding Principles on Business and Human Rights Articles 4-6.

97 Id. at Art. 4.

98 Código Nacional de Procedimientos Penales [G.N.P.P.] [National Code of Criminal Procedures], as amended, Article 421, Diario Oficial de la Federación [D.O.], March 5, 2014, (Mex.).

99 United Nations Guiding Principles on Business and Human Rights Article 5.

100 Id. at Art. 6.
} 


\section{E. Guiding Principle 7}

This principle establishes the obligation of States to guarantee that business enterprises will respect human rights in conflict-affected areas. ${ }^{101} \mathrm{John}$ Ruggie defines a conflict-affected area as a law-free zone with no central authority because the State is unwilling or unable to respect, protect and fulfill human rights. ${ }^{102}$ This generally occurs in countries involved in armed conflict or with authoritarian governments. It is a delicate problem since most gross human rights violations take place under these circumstances. ${ }^{103}$

To comply with this UNGP, countries must help corporations identify and prevent human rights risks and assist them in the implementation of procedures to minimize such risks. ${ }^{104}$ Moreover, States should suspend or deny public support to companies that do not cooperate in this effort, and ensure that measures are in place to sanction any involvement in human rights abuses. ${ }^{105}$

In this regard, the CLC can be very helpful because, as seen above, it obligates corporations to develop a due diligence program to detect and mitigate criminal risks. Hence, the assistance that States must provide to protect human rights can be more effective if corporations have already implemented preventive policies and compliance structures.

Moreover, the CLC is an enforcement mechanism to punish human rights abuses perpetrated by corporations, which can not only be applied within the Mexican territory but also beyond its borders. Article 4 of the FCG provides that the crimes committed abroad by or against Mexicans can be prosecuted and punished according to the federal laws when the defendant is domiciled in Mexico, when the crime has not already been judged elsewhere and the facts constitute a crime both in Mexico and in the country where they took place. ${ }^{106}$

For this reason, the CLC makes it possible to sanction not only the crimes committed in Mexico by domestic or foreign corporations, but also those perpetrated by Mexican companies in any other country. This extraterritorial feature of the CLC has enormous potential for the "home country" to punish human rights violations that occur in "host countries", that might be conflictaffected zones, where law enforcement is almost impossible.

\footnotetext{
101 Id. at Art. 7.

102 See Ruggie, supra note 15, Chapter 1.

103 Id.

104 United Nations Guiding Principles on Business and Human Rights Art. 7.

105 Id.

106 Código Penal Federal [C.P.F.] [Federal Criminal Code], as amended, Article 4, Diario Oficial de la Federación [D.O.], August 14, 1931, (Mex.).
} 


\section{F. Guiding Principles 8, 9 and 10}

These principles are related to the policy coherence that States must uphold. ${ }^{107}$ To this effect, countries must provide State-based institutions nationwide with information and support to fulfill their human rights obligations. ${ }^{108}$ This includes preparing and training investigation and law enforcement agencies to learn how to draw upon the CLC. In the international arena, States should promote business respect for human rights in the multilateral institutions of which they are members. ${ }^{109}$ In this case, if the CLC helps to comply with this duty, Mexico should encourage other countries to adopt similar measures in their criminal justice systems.

\section{Contribution to the Corporate Responsibility to Respect}

So far, I have analyzed how the adoption of the CLC contributes to the State duty to protect human rights. In this section, I will examine whether it is also useful to comply with the corporate responsibility to respect these rights.

\section{A. Guiding Principle 11}

This principle provides that corporations should respect human rights. ${ }^{110}$ Therefore, they must avoid infringing on the human rights of others and address any negative impact they might have. ${ }^{111}$

As discussed, this guideline has been severely criticized because its observation depends on corporate goodwill and entails a voluntary system of adoption and implementation of codes of conduct with no enforcement mechanisms. ${ }^{112}$ Therefore, it urges, but does not oblige companies to respect human rights.

In this respect, the adoption of the CLC establishes not only the moral responsibility, but also the binding obligation of corporations to respect human rights protected by criminal law. The CLC also encourages business enterprises to implement a criminal compliance program, for it is necessary for them to exclude or attenuate their liability. Furthermore, it enables criminal procedure to function as an enforcement mechanism to punish companies that violate human rights while equipping victims with a comprehensive set of substantive and procedural rights. For these reasons, the CLC has great

\footnotetext{
107 United Nations Guiding Principles on Business and Human Rights Arts. 8-10.

108 Id. at Art. 8.

109 Id. at Art. 10.

110 Id. at Art. 11

111 Id.

112 Weissbrodt \& Kruger, supra note 1, at 338.
} 
Esta revista forma parte del acervo de la Biblioteca Jurídica Virtual del Instituto de Investigaciones Jurídicas de la UNAM

potential to transform the international soft law of the UNGP into domestic hard law, and to empower the participation of civil society.

\section{B. Guiding Principle 12}

This UNGP determines the scope of human rights that corporations should respect. Since commercial activity is potentially harmful to almost all of the internationally recognized human rights, it states that business enterprises must respect, at least, those established in the International Bill of Human Rights, consisting of the Universal Declaration of Human Rights, the International Covenant on Civil and Political Rights and the International Covenant on Economic, Social and Cultural Rights, as well as the principles set out by the International Labour Organization in the Declaration on Fundamental Principles and Rights at Work. ${ }^{113}$

As analyzed in Chapter III, the CLC in Mexico is restricted to the crimes that are listed in Article 11 bis of the FGG. ${ }^{114}$ The next chart contains the criminal offenses that can be attributed to companies and the legal asset to be protected.

\section{Crimes Considered in the GLLP}

\begin{tabular}{|l|l|}
\hline \multicolumn{1}{|c|}{ Crime } & \multicolumn{1}{c|}{ Protected Asset } \\
\hline Terrorism & Several \\
\hline Drug-related & Health \\
\hline Corruption of minors and persons with disabilities & Unhindered development of personality \\
\hline Anti-corruption crimes & Public service \\
\hline Money forgery & Public finances \\
\hline Crimes against national wealth & National wealth \\
\hline Human trafficking & Several \\
\hline Vehicle theft and commercialization of stolen goods & Property \\
\hline Fraud & Property \\
\hline Concealment & Justice administration \\
\hline Money laundering & Several \\
\hline Environmental crimes & Environment \\
\hline Crimes against the author's right & Author's right \\
\hline Arms trafficking, introduction and gathering & Several \\
\hline Human organ commercialization & Several \\
\hline Kidnapping & Liberty \\
\hline Smuggling & Public finances \\
\hline
\end{tabular}

113 United Nations Guiding Principles on Business and Human Rights Art. 12.

114 Código Penal Federal [C.P.F.] [Federal Criminal Code], as amended, Art. 11 bis, Diario Oficial de la Federación [D.O.], August 14, 1931, (Mex.). 
Esta revista forma parte del acervo de la Biblioteca Jurídica Virtual del Instituto de Investigaciones Jurídicas de la UNAM

\begin{tabular}{|l|l|}
\hline \multicolumn{1}{|c|}{ Crime } & \multicolumn{1}{c|}{ Protected Asset } \\
\hline Tax fraud & Public finances \\
\hline Crimes against industrial property & Industrial property \\
\hline Banking and financial crimes & Financial system \\
\hline Bankruptcy-related crimes & Property \\
\hline Chemical substance-related crimes & Several \\
\hline
\end{tabular}

Considering that it is a small catalog, most of the human rights that corporations should respect fall outside the scope of the CLC. However, it would be desirable to reform this article so as to include other existing crimes and optimize the protection of a broader range of human rights.

The following charts draw a parallel between the human rights recognized in the International Bill of Rights and the Declaration on Fundamental Principles and Rights at Work, and the specific offence that is legally defined to protect them. It is also indicated whether these crimes can be attributed to corporations or not. The abbreviation N/A is used when there is no offence established in law that directly aims to protect the corresponding human right.

\section{Universal Declaration of Human Rights}

\begin{tabular}{|c|c|c|c|c|}
\hline Art. & Human Right & Crime & Legal Basis & $C L C$ \\
\hline 2 & Non-discrimination & Discrimination & Art. 149 ter FCC & $\mathrm{NO}$ \\
\hline \multirow{5}{*}{3} & \multirow{2}{*}{ Life } & Homicide & Art. 302 FCG & $\mathrm{NO}$ \\
\hline & & Genocide & Art. 149 bis FCG & $\mathrm{NO}$ \\
\hline & Physical integrity & Injuries & Art. 288 FGC & $\mathrm{NO}$ \\
\hline & \multirow{2}{*}{$\begin{array}{l}\text { Liberty and security of } \\
\text { person }\end{array}$} & $\begin{array}{l}\text { Unlawful deprivation } \\
\text { of liberty }\end{array}$ & Art. 364 FCG & $\mathrm{NO}$ \\
\hline & & Kidnapping & Special Law & YES \\
\hline 4 & $\begin{array}{l}\text { Prohibition of slavery or } \\
\text { servitude }\end{array}$ & Human trafficking & Special Law & YES \\
\hline 5 & $\begin{array}{l}\text { Prohibition of torture, cruel, } \\
\text { inhuman or degrading } \\
\text { treatment or punishment }\end{array}$ & $\begin{array}{l}\text { Torture, cruel, inhuman } \\
\text { or degrading treatment } \\
\text { or punishment }\end{array}$ & Special Law & $\mathrm{NO}$ \\
\hline 6 & Legal personality & N/A & N/A & N/A \\
\hline 7 & $\begin{array}{l}\text { Equality and non-discrimi- } \\
\text { nation }\end{array}$ & Discrimination & Art. 149 ter FCC & $\mathrm{NO}$ \\
\hline 8 & $\begin{array}{l}\text { Access to justice and effecti- } \\
\text { ve remedy }\end{array}$ & Denial of Justice & $\begin{array}{l}\text { Art. } 215 \text { (IV) } \\
\text { FGG }\end{array}$ & $\mathrm{NO}$ \\
\hline 9 & $\begin{array}{l}\text { Prohibition of arbitrary } \\
\text { arrest, detention or exile }\end{array}$ & Abuse of authority & $\begin{array}{l}\text { Art. } 215(\mathrm{VI}) \\
\text { FCG }\end{array}$ & $\mathrm{NO}$ \\
\hline 10 & $\begin{array}{l}\text { Public hearing, independent } \\
\text { and impartial tribunal }\end{array}$ & $\begin{array}{l}\text { Against justice } \\
\text { administration }\end{array}$ & Art. 225 FCG & $\mathrm{NO}$ \\
\hline
\end{tabular}


Esta revista forma parte del acervo de la Biblioteca Jurídica Virtual del Instituto de Investigaciones Jurídicas de la UNAM

\begin{tabular}{|c|c|c|c|c|}
\hline Art. & Human Right & Crime & Legal Basis & $C L C$ \\
\hline 11 & $\begin{array}{l}\text { Presumption of innocence } \\
\text { and procedural rights }\end{array}$ & $\begin{array}{l}\text { Against justice } \\
\text { administration }\end{array}$ & Art. 225 FGC & $\mathrm{NO}$ \\
\hline 12 & $\begin{array}{l}\text { Prohibition of arbitrary } \\
\text { interference with privacy, } \\
\text { family, home, corresponden- } \\
\text { ce, honor and reputation }\end{array}$ & $\begin{array}{l}\text { Violation of } \\
\text { correspondence } \\
\text { and communications }\end{array}$ & Art. 173 FCG & $\mathrm{NO}$ \\
\hline \multirow{2}{*}{13} & \multirow{2}{*}{$\begin{array}{l}\text { Freedom of movement } \\
\text { and residence }\end{array}$} & $\begin{array}{l}\text { Unlawful deprivation } \\
\text { of liberty }\end{array}$ & Art. 364 FCG & $\mathrm{NO}$ \\
\hline & & Attacks to public roads & Art. 165 FCG & $\mathrm{NO}$ \\
\hline 14 & Asylum from prosecution & N/A & N/A & N/A \\
\hline 15 & Nationality & N/A & N/A & N/A \\
\hline 16 & $\begin{array}{l}\text { Consent to marriage } \\
\text { and family rights }\end{array}$ & Human trafficking & Special Law & YES \\
\hline \multirow{6}{*}{17} & \multirow{6}{*}{ Private property } & Theft & Art. 367 FCG & YES \\
\hline & & Abuse of confidence & Art. 382 FGC & $\mathrm{NO}$ \\
\hline & & Fraud & Art. 386 FCC & YES \\
\hline & & Extortion & Art. $390 \mathrm{FCC}$ & $\mathrm{NO}$ \\
\hline & & Dispossession of land & Art. 395 FCC & $\mathrm{NO}$ \\
\hline & & Damages & Art. 397 FCC & $\mathrm{NO}$ \\
\hline 18 & $\begin{array}{l}\text { Freedom of thought, } \\
\text { conscience and religion }\end{array}$ & N/A & N/A & N/A \\
\hline 19 & $\begin{array}{l}\text { Freedom of opinion and } \\
\text { expression }\end{array}$ & $\mathrm{N} / \mathrm{A}$ & N/A & $\mathrm{N} / \mathrm{A}$ \\
\hline 20 & $\begin{array}{l}\text { Freedom of assembly and } \\
\text { association }\end{array}$ & N/A & $\mathrm{N} / \mathrm{A}$ & N/A \\
\hline 21 & Political rights & Electoral crimes & Special law & $\mathrm{NO}$ \\
\hline 22 & Social security & Social security crimes & Special law & $\mathrm{NO}$ \\
\hline 23 & Labor rights & Labor crimes & Special law & $\mathrm{NO}$ \\
\hline 24 & Rest and leisure & Labor crimes & Special law & $\mathrm{NO}$ \\
\hline 25 & $\begin{array}{l}\text { Adequate standard of } \\
\text { living and health }\end{array}$ & $\mathrm{N} / \mathrm{A}$ & $\mathrm{N} / \mathrm{A}$ & N/A \\
\hline 26 & Education & N/A & N/A & N/A \\
\hline 27 & $\begin{array}{l}\text { Cultural life and scientific } \\
\text { advancements }\end{array}$ & N/A & $\mathrm{N} / \mathrm{A}$ & N/A \\
\hline 27 & Author's right & $\begin{array}{l}\text { Against the author's } \\
\text { right }\end{array}$ & Art. 424 FGG & YES \\
\hline
\end{tabular}


Esta revista forma parte del acervo de la Biblioteca Jurídica Virtual del Instituto de Investigaciones Jurídicas de la UNAM

International Govenant on Givil and Political Rights

\begin{tabular}{|c|c|c|c|c|}
\hline Art. & Human Right & Crime & Legal Basis & $C L C$ \\
\hline 1 & Self-determination & N/A & N/A & $\mathrm{N} / \mathrm{A}$ \\
\hline 2 & Non-discrimination & Discrimination & $\begin{array}{l}\text { Art. } 149 \text { ter } \\
\text { FCG }\end{array}$ & $\mathrm{NO}$ \\
\hline 3 & $\begin{array}{l}\text { Equality between } \\
\text { men and women }\end{array}$ & Discrimination & $\begin{array}{l}\text { Art. } 149 \text { ter } \\
\text { FCG }\end{array}$ & NO \\
\hline \multirow{3}{*}{6} & \multirow{2}{*}{ Life } & Homicide & $\begin{array}{c}\text { Art. } 302 \\
\text { FCG }\end{array}$ & NO \\
\hline & & Genocide & $\begin{array}{c}\text { Art. } 149 \text { bis } \\
\text { FCG }\end{array}$ & $\mathrm{NO}$ \\
\hline & Physical integrity & Injuries & $\begin{array}{c}\text { Art. } 288 \\
\text { FCG }\end{array}$ & $\mathrm{NO}$ \\
\hline 7 & $\begin{array}{l}\text { Prohibition of torture, cruel, } \\
\text { inhuman or degrading } \\
\text { treatment or punishment. }\end{array}$ & $\begin{array}{l}\text { Torture, cruel, inhuman } \\
\text { or degrading treatment or } \\
\text { punishment. }\end{array}$ & Special Law & $\mathrm{NO}$ \\
\hline 8 & $\begin{array}{l}\text { Prohibition of slavery, } \\
\text { servitude, compulsory } \\
\text { labor }\end{array}$ & Human trafficking & Special Law & YES \\
\hline \multirow{3}{*}{9} & \multirow{2}{*}{$\begin{array}{l}\text { Liberty and security } \\
\text { of person }\end{array}$} & $\begin{array}{l}\text { Unlawful deprivation } \\
\text { of liberty }\end{array}$ & $\begin{array}{l}\text { Art. } 364 \\
\text { FCG }\end{array}$ & $\mathrm{NO}$ \\
\hline & & Kidnapping & Special Law & YES \\
\hline & $\begin{array}{l}\text { Prohibition of arbitrary } \\
\text { arrest or detention. }\end{array}$ & Abuse of authority & $\begin{array}{l}\text { Art. } 215(\mathrm{VI}) \\
\quad \text { FCG }\end{array}$ & NO \\
\hline 11 & $\begin{array}{l}\text { Prohibition } \\
\text { of imprisonment } \\
\text { for civil debts }\end{array}$ & $\mathrm{N} / \mathrm{A}$ & N/A & $\mathrm{N} / \mathrm{A}$ \\
\hline 12 & $\begin{array}{l}\text { Freedom of movement } \\
\text { and residence }\end{array}$ & $\begin{array}{l}\text { Unlawful deprivation } \\
\text { of liberty }\end{array}$ & $\begin{array}{c}\text { Art. } 364 \\
\text { FCG }\end{array}$ & $\mathrm{NO}$ \\
\hline 14 & $\begin{array}{l}\text { Presumption of innocence } \\
\text { and procedural rights }\end{array}$ & $\begin{array}{l}\text { Against justice } \\
\text { administration }\end{array}$ & $\begin{array}{l}\text { Art. } 225 \\
\text { FCC }\end{array}$ & $\mathrm{NO}$ \\
\hline 15 & $\begin{array}{l}\text { Non-retroactivity } \\
\text { of criminal laws }\end{array}$ & N/A & $\mathrm{N} / \mathrm{A}$ & $\mathrm{N} / \mathrm{A}$ \\
\hline 16 & Legal personality & N/A & N/A & $\mathrm{N} / \mathrm{A}$ \\
\hline 17 & $\begin{array}{l}\text { Prohibition of arbitrary } \\
\text { interference with privacy, } \\
\text { family, home, corresponden- } \\
\text { ce, honor and reputation }\end{array}$ & $\begin{array}{l}\text { Violation of } \\
\text { correspondence } \\
\text { and communications }\end{array}$ & $\begin{array}{l}\text { Art. } 173 \\
\text { FCG }\end{array}$ & $\mathrm{NO}$ \\
\hline 18 & $\begin{array}{l}\text { Freedom of thought, } \\
\text { conscience and religion }\end{array}$ & $\mathrm{N} / \mathrm{A}$ & N/A & $\mathrm{N} / \mathrm{A}$ \\
\hline 19 & $\begin{array}{l}\text { Freedom of opinion } \\
\text { and expression }\end{array}$ & N/A & N/A & $\mathrm{N} / \mathrm{A}$ \\
\hline 21 & Freedom of assembly & N/A & N/A & $\mathrm{N} / \mathrm{A}$ \\
\hline 22 & Freedom of association & N/A & $\mathrm{N} / \mathrm{A}$ & N/A \\
\hline
\end{tabular}


Esta revista forma parte del acervo de la Biblioteca Jurídica Virtual del Instituto de Investigaciones Jurídicas de la UNAM

\begin{tabular}{|c|l|l|c|c|}
\hline Art. & \multicolumn{1}{|c|}{ Human Right } & \multicolumn{1}{|c|}{ Crime } & Legal Basis & CLC \\
\hline 23 & $\begin{array}{l}\text { Consented marriage } \\
\text { and family rights }\end{array}$ & Human trafficking & Special Law & YES \\
\hline 24 & Name and nationality & N/A & N/A & N/A \\
\hline 25 & Political rights & Electoral crimes & Special law & NO \\
\hline 26 & $\begin{array}{l}\text { Equality and } \\
\text { non-discrimination }\end{array}$ & Discrimination & $\begin{array}{c}\text { Art. 149 ter } \\
\text { FCG }\end{array}$ & NO \\
\hline
\end{tabular}

\section{International Govenant on Economic,} Social and Gultural Rights

\begin{tabular}{|c|c|c|c|c|}
\hline Art. & Human Right & Crime & Legal Basis & $C L C$ \\
\hline 1 & Self-determination & N/A & N/A & $\mathrm{N} / \mathrm{A}$ \\
\hline 3 & $\begin{array}{l}\text { Equality between } \\
\text { men and women }\end{array}$ & Discrimination & Art. 149 ter FCG & $\mathrm{NO}$ \\
\hline 6 & Right to work & $\mathrm{N} / \mathrm{A}$ & N/A & N/A \\
\hline \multirow{3}{*}{7} & $\begin{array}{l}\text { Minimum } \\
\text { remuneration }\end{array}$ & Labor crime & Special law & $\mathrm{NO}$ \\
\hline & $\begin{array}{l}\text { Safe and healthy } \\
\text { working conditions }\end{array}$ & Labor crime & Special law & NO \\
\hline & Rest and leisure & Labor crime & Special law & $\mathrm{NO}$ \\
\hline \multirow{2}{*}{8} & To form unions & $\mathrm{N} / \mathrm{A}$ & N/A & N/A \\
\hline & Strike & N/A & N/A & $\mathrm{N} / \mathrm{A}$ \\
\hline 9 & Social security & Social security crimes & Special law & $\mathrm{NO}$ \\
\hline 10 & $\begin{array}{l}\text { Consented marriage } \\
\text { and family rights }\end{array}$ & Human trafficking & Special Law & YES \\
\hline 11 & $\begin{array}{l}\text { Adequate standard } \\
\text { of living }\end{array}$ & N/A & $\mathrm{N} / \mathrm{A}$ & $\mathrm{N} / \mathrm{A}$ \\
\hline 12 & $\begin{array}{l}\text { The highest attainable } \\
\text { standard of health }\end{array}$ & N/A & N/A & $\mathrm{N} / \mathrm{A}$ \\
\hline 13 & Education & N/A & N/A & N/A \\
\hline 14 & Education & N/A & N/A & $\mathrm{N} / \mathrm{A}$ \\
\hline \multirow{2}{*}{15} & Cultural life & N/A & N/A & $\mathrm{N} / \mathrm{A}$ \\
\hline & Scientific progress & N/A & N/A & $\mathrm{N} / \mathrm{A}$ \\
\hline
\end{tabular}


Esta revista forma parte del acervo de la Biblioteca Jurídica Virtual del Instituto de Investigaciones Jurídicas de la UNAM

\section{Ilo Declaration on Fundamental Principles AND RightS AT WORK}

\begin{tabular}{|c|l|l|l|c|}
\hline \multirow{2}{*}{ Art. } & \multicolumn{1}{|c|}{ Human Right } & \multicolumn{1}{|c|}{ Crime } & Legal Basis & CLC \\
\hline \multirow{3}{*}{2} & $\begin{array}{l}\text { Freedom of association } \\
\text { and collective bargaining }\end{array}$ & N/A & N/A & N/A \\
\cline { 2 - 5 } & Elimination of forced labor & Human trafficking & Special Law & YES \\
\cline { 2 - 5 } & Abolition of child labor & Labor crime & Special law & NO \\
\cline { 2 - 5 } & $\begin{array}{l}\text { Non-discrimination in } \\
\text { employment and occupation }\end{array}$ & Discrimination & 149 ter FCC & NO \\
\hline
\end{tabular}

As seen, in terms of civil and political rights, Mexican legislation defines several offences that intend to protect almost all of them. The ones that are not directly addressed, such as the right to a name, nationality or legal personality, can be indirectly protected by other figures such as human trafficking. Moreover, in regards to economic, social and cultural rights, there is specific criminal protection for labor and social security rights, as well as for the principle of non-discrimination. Furthermore, the progressive achievement of the rights to health, education, adequate standard of living, enjoyment of cultural life and scientific progress can be indirectly protected by the punishment of anti-corruption crimes.

Therefore, the currently limited contribution of the CLC to comply with this UNGP can be significantly enhanced if the catalog of crimes that can be attributed to corporations is expanded as follows:

\section{Crimes that should be Considered in the CLLP}

\begin{tabular}{|l|l|c|}
\hline \multicolumn{1}{|c|}{ Crime } & \multicolumn{1}{c|}{ Protected Human Right } & \multicolumn{1}{c|}{ Legal Basis } \\
\hline Discrimination & Non-discrimination & Art. 149 ter FCG \\
\hline Homicide & Life & Art. 302 FCG \\
\hline Genocide & Life & Art. 149 bis FGC \\
\hline Injuries & Physical integrity & Art. 288 FCG \\
\hline Against reproductive rights & Reproductive rights & Art. 199 FCG \\
\hline $\begin{array}{l}\text { Unlawful deprivation } \\
\text { of liberty }\end{array}$ & Personal liberty and security & Art. 364 FCG \\
\hline $\begin{array}{l}\text { Torture, cruel, inhuman } \\
\text { or degrading treatment } \\
\text { or punishment. }\end{array}$ & $\begin{array}{l}\text { Prohibition of torture, cruel, } \\
\text { inhuman or degrading } \\
\text { treatment or punishment. }\end{array}$ & Special law \\
\hline Denial of justice & Access to justice & Art. 215 (IV) FCG \\
\hline Abuse of authority & Several & Art. 215 (VI) FCG \\
\hline
\end{tabular}


Esta revista forma parte del acervo de la Biblioteca Jurídica Virtual del Instituto de Investigaciones Jurídicas de la UNAM

\begin{tabular}{|c|c|c|}
\hline Crime & Protected Human Right & Legal Basis \\
\hline $\begin{array}{l}\text { Against justice } \\
\text { administration }\end{array}$ & $\begin{array}{l}\text { Legal certainty, } \\
\text { procedural rights }\end{array}$ & Art. 225 FCG \\
\hline $\begin{array}{l}\text { Violation } \\
\text { of correspondence } \\
\text { and communications }\end{array}$ & $\begin{array}{l}\text { Privacy, inviolability } \\
\text { of communications }\end{array}$ & Art. 173 FCG \\
\hline Attacks to public roads & Freedom of transit & Art. 165 FCG \\
\hline Theft & Property & Art. 367 FCG \\
\hline Abuse of confidence & Property & Art. 382 FCG \\
\hline Extortion & Property & Art. $390 \mathrm{FCG}$ \\
\hline $\begin{array}{l}\text { Dispossession of land } \\
\text { and water sources }\end{array}$ & Property & Art. 395 FCG \\
\hline Damages & Property & Art. 397 FCG \\
\hline Electoral crimes & Political rights & Special law \\
\hline Social security crimes & Social security rights & Special law \\
\hline Labor crimes & Labor rights & Special law \\
\hline Child pornography & $\begin{array}{l}\text { Unhindered development } \\
\text { of personality }\end{array}$ & Art. 202 FGG \\
\hline Sexual tourism of minors & $\begin{array}{l}\text { Unhindered development } \\
\text { of personality }\end{array}$ & Art. 203 FCG \\
\hline Prostitution of minors & $\begin{array}{l}\text { Unhindered development } \\
\text { of personality }\end{array}$ & Art. 204 FCG \\
\hline Pederasty & $\begin{array}{l}\text { Sexual liberty } \\
\text { and unhindered } \\
\text { development of personality }\end{array}$ & Art. 209 bis FCG \\
\hline $\begin{array}{l}\text { Rape, sexual assault, } \\
\text { sexual harassment. }\end{array}$ & $\begin{array}{l}\text { Sexual liberty } \\
\text { and sexual development }\end{array}$ & $\begin{array}{c}259 \text { bis, } 260 \text { and } 265 \\
\text { FCG }\end{array}$ \\
\hline
\end{tabular}

This extension of the catalog is not a legislative illusion, but is a real possibility. For example, at the local level, the state of Quintana Roo has adopted a broader list of crimes that can be attributed to corporations, such as homicide, injuries, and dispossession of land, among others, which are often violated by companies. ${ }^{115}$ Hence, there is no limitation for the federal congress to place the CLC within the scope of protection established by this UNGP.

\section{G. Guiding Principle 13}

This principle provides that corporations should avoid causing harm or contributing to adverse human rights impacts, not only through their opera-

115 See Código Penal para el Estado de Quintana Roo 2017 [Criminal Code for the State of Quintana Roo] (Mexico) Art. 18 nonies. 
tions, but also within the activities of their business partners. ${ }^{116}$ To this effect, the CLC can be very useful, taking into account the fact that crimes can be committed by one or several actors, ${ }^{117}$ and also result from actions or omissions. ${ }^{118}$ In this sense, if just one corporation is involved in a crime, it can be punished as a direct perpetrator. ${ }^{19}$ If a business partner commits the crime, the corporation can be sanctioned as joint-perpetrator by omission if the company fails to comply with its preventive duties within the supply chain. ${ }^{120}$

\section{Guiding Principle 14}

All business enterprises, regardless of their size, can have severe human rights impacts. Therefore, this principle declares that the responsibility to respect applies to all corporations. ${ }^{121}$ However, the steps they take to meet this requirement are expected to be proportional and suitable to their size, sector, operational context, ownership and structure. ${ }^{122}$

The principle of equal application of the law is also embraced by the CLC, as Article 11 bis of the FGC establishes that all legal persons, without distinction, can be punished for crimes. ${ }^{123}$ Even when the FGC does not provide much detail about the requirements of a criminal compliance program, Article 18 quinquies of the Criminal Code for the state of Quintana Roo stipulates that corporate governance models should be fitting for each business enterprise. ${ }^{124}$ Consequently, the CLC can be arranged along the lines of this guideline.

\section{E. Guiding Principles 15 and 16}

In a similar sense, principle 15 says that the policies adopted by corporations to comply with their responsibility should include three essential aspects: the specific commitment to respect human rights, a human rights due

116 United Nations Guiding Principles on Business and Human Rights Art. 13.

117 Código Penal Federal [C.P.F.] [Federal Criminal Code], as amended, Art. 13, Diario Oficial de la Federación [D.O.], August 14, 1931, (Mex.).

118 Id. at Art. 7.

119 Id. at Art. 13.

120 Id. at Art. 7.

121 United Nations Guiding Principles on Business and Human Rights Art. 14.

$122 I d$

123 Código Penal Federal [C.P.F.] [Federal Criminal Code], as amended, Article 11 bis, Diario Oficial de la Federación [D.O.], August 14, 1931, (Mex.).

124 Código Penal para el Estado de Quintana Roo [C.P.Q.R.] [Criminal Code for the State of Quintana Roo] as amended, Article 18 quinquies, Periódico Oficial del Estado de Quintana Roo [P.O.Q.R.], March 29, 1991, (Quintana Roo, Mex.). 
diligence process and mechanisms to provide remediation of any violation. ${ }^{125}$ Meanwhile, principle 16 explains that the corporate commitment to respect human rights should be approved by the most senior level of the corporation and be communicated to its personnel and business partners. ${ }^{126}$

In the absence of a specific provision in the $\mathrm{FCC}$, the corporate governance adopted by the CLC to prevent the commission of crimes can be informed by these guidelines. Thus, a criminal compliance program should include a meeting of shareholders or directors to formally adopt the commitment to prevent crimes from being committed, as well as communication channels to make this policy known both internally and externally.

\section{F. Guiding Principles 17, 18, 19, 20 and 21}

These principles explain the requirements of a human rights due diligence. ${ }^{127}$ The first stage of this process is to identify the risks against human rights generated by the corporation's commercial activities and its supply chain. ${ }^{128}$ To this effect, companies should ensure the participation of workers, consumers, communities and other potentially affected groups. ${ }^{129}$ The second phase is to prevent and mitigate such risks by adopting internal policies and protocols, as well as the allocation of financial resources to ensure their communication, implementation, evaluation and revision. ${ }^{130}$

As seen in Chapter III, the adoption of an effective criminal compliance program excludes or attenuates corporate criminal liability, for it aims at detecting, preventing and mitigating criminal risks. If the legal definition of crimes aims to protect human rights in the form of legal assets, a criminal compliance program is, to some extent, a human rights due diligence. However, the former cannot replace the latter because, even if the scope of application of the CLC is extended to all the offences that are legally defined to protect human rights, it would not encompass all possible abuses. While criminal law only sanctions serious offenses to legally protected assets, human rights violations are caused by many other means, even minor offenses that involve administrative infractions or civil liability. Nevertheless, a criminal compliance program can be an essential component of a human rights due diligence.

One relevant feature required by these UNGP is the participation of the civil society in the identification and assessment of the risks. There is no provision in Mexico that requires civil participation in a criminal compliance program. However, it would be desirable for the FCG to call for such ac-

\footnotetext{
125 United Nations Guiding Principles on Business and Human Rights Article 15.

126 Id. at Art. 16.

127 Id. at Art. 17.

128 Id. at Art. 18

129 Id.

130 Id. at Arts. 19-21.
} 
tion because, if violations generally occur in situations with significant power asymmetries, an effective way to prevent them is by empowering potential victims. ${ }^{131}$

\section{Access to Remedy}

In the last two sections, I have examined how the implementation of the CLC helps to comply with the UNGP in regards to the State duty to protect human rights and corporate responsibility to respect human rights. To finalize the analysis, in this chapter I will evaluate the function of the GLC as a remedial mechanism for human rights violations.

\section{A. Guiding Principles 25, 26 and 27}

Besides the duty to protect human rights, these principles provide that the State must also ensure effective remedy to the victims. ${ }^{132}$ These State-based mechanisms can be judicial or non-judicial in nature. ${ }^{133}$ In this sense, the adoption of the CLC helps to meet this obligation, since it constitutes a legislative measure that enables a State-based judicial procedure to investigate and punish the crimes committed by corporations, which might involve the violation of human rights.

The sanctions that can be applied to business enterprises seek not only punishment, but also compensation. ${ }^{134}$ Thus, after the commission of a crime, corporations can be sentenced to full remediation of the damages, which includes, at least: the restitution of the assets obtained through the crime or the payment of their cost; compensation for material and moral harm, indirect damages and the loss of profit, the loss of employment or educational opportunities, medical and psychological assistance; public apologies and guarantees of non-repetition. ${ }^{135}$

Moreover, the CLC allows alternative dispute resolution mechanisms, such as reparatory agreements and conditional suspension of the process, which entail mediation or conciliation between the parties and the payment for the full remediation of the damages. ${ }^{136}$ Consequently, the CLC also allows Statebased non-judicial grievance mechanisms in favor of the victims.

131 See Melish, supra note 45; and Jochnick, supra note 47.

132 United Nations Guiding Principles on Business and Human Rights Art. 25.

133 Id. at Arts. 26-27.

134 Código Penal Federal [C.P.F.] [Federal Criminal Code], as amended, Article 422, Diario

Oficial de la Federación [D.O.], August 14, 1931, (Mex.).

135 Id. at Art. 30.

136 Id. at Art. 424. 
Furthermore, the CLC has other convenient features. For example, it can be attributed directly to the corporation, regardless the liability of the natural persons involved in the crime, it has extraterritorial application against Mexican companies that operate in a host country that might be unwilling or unable to prosecute them, and it is free of charge for the victims. Consequently, the CLC contributes to overcoming some legal barriers to the effective access to justice.

\section{B. Guiding Principles 28, 29, 30 and 31}

These principles provide that, besides the State-based judicial and nonjudicial grievance mechanisms, States must encourage the implementation of non-State based alternatives, such as internal procedures administered by corporations alone or with the participation of other stakeholders. ${ }^{137}$ Companies must also implement and collaborate in operational-level grievance mechanisms, to address any adverse impact on human rights in a timely manner. ${ }^{138}$

With the adoption of the CLC, companies are required to adopt a criminal compliance program that can include a channel to file claims, as well as a dialogue-based and operational-level grievance mechanism (informed by the principles established in UNGP 31), in order to provide adequate remedy for crimes without the need of initiating a criminal procedure. This mechanism can be applied to crimes that only affect particular interests, since a direct claim for the victim is required for such crimes to be prosecuted. ${ }^{139}$ In the case of crimes that are prosecuted ex officio, the implementation of a nonState based grievance mechanism by which the corporation provides compensation to the victim can attenuate its responsibility. ${ }^{140}$

\section{Summary}

After evaluating the CLC in light of the UNGP, we can conclude that the CLC plays a significant role in the business and human rights sub-ecosystem, not only because of its direct contributions, but also for the mutually reinforcing connections it creates with corporate and civil governance. However, there are still many areas in which its performance can be optimized.

To finish this analysis, the next chart recaps the individual contributions, symbiotic relations and shortcomings of the CLG in relation to each UNGP.

137 United Nations Guiding Principles on Business and Human Rights Art. 28.

138 Id. at Art. 29

139 Código Nacional de Procedimientos Penales [C.N.P.P.] [National Code of Criminal Procedures], as amended, Article 225, Diario Oficial de la Federación [D.O.], March 5, 2014, (Mex.).

140 Código Penal Federal [C.P.F.] [Federal Criminal Code], as amended, Article 11 bis, Diario Oficial de la Federación [D.O.], August 14, 1931, (Mex.). 
Esta revista forma parte del acervo de la Biblioteca Jurídica Virtual del Instituto de Investigaciones Jurídicas de la UNAM

\begin{tabular}{|c|c|c|c|}
\hline$U N G P$ & $\begin{array}{c}\text { Individual Contribution of the } \\
\text { CLC to the Field of Business and } \\
\text { Human Rights }\end{array}$ & $\begin{array}{l}\text { Symbiotic Relation with } \\
\text { Corporate and Civil } \\
\text { Governance }\end{array}$ & $\begin{array}{l}\text { Suggestions to Optimize } \\
\text { its Contribution }\end{array}$ \\
\hline 1 & $\begin{array}{l}\text { It represents an appropriate } \\
\text { legislative step to protect } \\
\text { against human rights viola- } \\
\text { tions by corporations. }\end{array}$ & N/A & $\begin{array}{l}\text { Expand the catalog } \\
\text { of crimes that can be } \\
\text { attributed to corpora- } \\
\text { tions to broaden the } \\
\text { scope of protection. }\end{array}$ \\
\hline 2 & $\begin{array}{l}\text { It helps to create the social } \\
\text { expectation that corpora- } \\
\text { tions should respect the hu- } \\
\text { man rights that are protect- } \\
\text { ed by the criminal offenses } \\
\text { defined in law. }\end{array}$ & $\begin{array}{l}\text { It raises awareness in } \\
\text { corporations about their } \\
\text { duty to respect human } \\
\text { rights and creates the } \\
\text { social expectation that } \\
\text { they should do so. }\end{array}$ & $\begin{array}{l}\text { Expand the catalog } \\
\text { of crimes that can be } \\
\text { attributed to corpora- } \\
\text { tions to broaden the } \\
\text { scope of protection. }\end{array}$ \\
\hline 3 & $\begin{array}{l}\text { It encourages corporations to } \\
\text { develop a criminal complian- } \\
\text { ce program to rule out or at- } \\
\text { tenuate their liability, which } \\
\text { also demands corporate } \\
\text { respect for human rights. }\end{array}$ & $\begin{array}{l}\text { It requires the imple- } \\
\text { mentation of a criminal } \\
\text { compliance program in } \\
\text { corporate governance } \\
\text { to rule out or attenuate } \\
\text { the liability. }\end{array}$ & $\begin{array}{l}\text { Guide corporations } \\
\text { on how to develop a } \\
\text { criminal compliance } \\
\text { program, including the } \\
\text { participation of civil } \\
\text { society. }\end{array}$ \\
\hline 4 & N/A & N/A & N/A \\
\hline 5 & $\begin{array}{l}\text { It can punish corporations } \\
\text { that provide privatized } \\
\text { services with a direct impact } \\
\text { on human rights. }\end{array}$ & N/A & $\begin{array}{l}\text { Expand the catalog } \\
\text { of crimes that can be } \\
\text { attributed to corpora- } \\
\text { tions to broaden the } \\
\text { scope of protection. }\end{array}$ \\
\hline 6 & N/A & N/A & $\begin{array}{l}\text { Require a criminal } \\
\text { compliance program as } \\
\text { a condition for public } \\
\text { contracting. }\end{array}$ \\
\hline 7 & $\begin{array}{l}\text { It enables the extraterrito- } \\
\text { rial application of criminal } \\
\text { law to sanction violations } \\
\text { committed by Mexican } \\
\text { corporations in conflict- } \\
\text { affected areas. }\end{array}$ & N/A & $\begin{array}{l}\text { Expand the catalog } \\
\text { of crimes that can be } \\
\text { attributed to corpora- } \\
\text { tions to broaden the } \\
\text { scope of protection. }\end{array}$ \\
\hline $8-10$ & N/A & N/A & $\begin{array}{l}\text { Promote the adoption } \\
\text { of the CLC by other } \\
\text { countries in multilate- } \\
\text { ral organizations. }\end{array}$ \\
\hline 11 & $\begin{array}{l}\text { It establishes a binding } \\
\text { obligation for corporations } \\
\text { to respect the human rights } \\
\text { that are protected by the } \\
\text { offences defined in law, and } \\
\text { criminal procedure has the } \\
\text { function of an enforcement } \\
\text { mechanism. }\end{array}$ & $\begin{array}{l}\text { It equips civil society } \\
\text { with a comprehensive } \\
\text { set of substantive and } \\
\text { procedural rights, in } \\
\text { case they become vic- } \\
\text { tims of a crime. }\end{array}$ & $\begin{array}{l}\text { Expand the catalog } \\
\text { of crimes that can be } \\
\text { attributed to corpo- } \\
\text { rations to amplify the } \\
\text { scope of protection. }\end{array}$ \\
\hline
\end{tabular}


Esta revista forma parte del acervo de la Biblioteca Jurídica Virtual del Instituto de Investigaciones Jurídicas de la UNAM

\begin{tabular}{|c|c|c|c|}
\hline$U N G P$ & $\begin{array}{c}\text { Individual Contribution of the } \\
\text { CLC to the Field of Business and } \\
\text { Human Rights }\end{array}$ & $\begin{array}{c}\text { Symbiotic Relation with } \\
\text { Corporate and Civil } \\
\text { Governance }\end{array}$ & $\begin{array}{l}\text { Suggestions to Optimize } \\
\text { its Contribution }\end{array}$ \\
\hline 12 & $\begin{array}{l}\text { It lists crimes that can be } \\
\text { attributed to corporations. }\end{array}$ & N/A & $\begin{array}{l}\text { Expand the catalog } \\
\text { of crimes that can be } \\
\text { attributed to corpo- } \\
\text { rations to encompass } \\
\text { most internationally } \\
\text { recognized human } \\
\text { rights. }\end{array}$ \\
\hline 13 & $\begin{array}{l}\text { It is possible to sanction } \\
\text { corporations if they fail to } \\
\text { comply with their preventive } \\
\text { duties, even by omission, } \\
\text { within the supply chain. }\end{array}$ & $\begin{array}{l}\text { It requires corporations } \\
\text { to demand that their } \\
\text { business partners in the } \\
\text { supply chain uphold the } \\
\text { same respect for human } \\
\text { rights. }\end{array}$ & $\begin{array}{l}\text { Clarify the preventive } \\
\text { duties of corporations } \\
\text { within the supply } \\
\text { chain. }\end{array}$ \\
\hline 14 & $\begin{array}{l}\text { It establishes that all private } \\
\text { corporations can be punis- } \\
\text { hed for the commission of } \\
\text { such crimes without any } \\
\text { distinction. }\end{array}$ & N/A & $\begin{array}{l}\text { Emphasize that the } \\
\text { criminal compliance } \\
\text { program should be } \\
\text { proportional to the } \\
\text { size, sector and opera- } \\
\text { tional context of the } \\
\text { corporation. }\end{array}$ \\
\hline $15-16$ & N/A & N/A & $\begin{array}{l}\text { Specify that the crimi- } \\
\text { nal compliance pro- } \\
\text { gram must contain the } \\
\text { specific commitment to } \\
\text { respect human rights } \\
\text { and be approved by } \\
\text { senior levels of the } \\
\text { corporation. }\end{array}$ \\
\hline $17-24$ & $\begin{array}{l}\text { The criminal compliance } \\
\text { program can be an essential } \\
\text { component of a human } \\
\text { rights due diligence. }\end{array}$ & N/A & $\begin{array}{l}\text { Guide corporations } \\
\text { on how to develop a } \\
\text { criminal compliance } \\
\text { program with the } \\
\text { participation of civil } \\
\text { society. }\end{array}$ \\
\hline $25-27$ & $\begin{array}{l}\text { It enables a State-based } \\
\text { judicial procedure to obtain } \\
\text { a remedy and allows State- } \\
\text { based non-judicial alter- } \\
\text { native dispute resolution } \\
\text { mechanisms. }\end{array}$ & $\begin{array}{l}\text { It gives victims the right } \\
\text { to full remediation of } \\
\text { the damages. }\end{array}$ & $\begin{array}{l}\text { Expand the catalog of } \\
\text { crimes to amplify the } \\
\text { scope of protection. }\end{array}$ \\
\hline $28-31$ & $\mathrm{~N} / \mathrm{A}$ & N/A & $\begin{array}{l}\text { Specify that a criminal } \\
\text { compliance program } \\
\text { should include a } \\
\text { dialogue-based and } \\
\text { operational-level grie- } \\
\text { vance mechanism. }\end{array}$ \\
\hline
\end{tabular}




\section{Gonclusion}

The findings of this research have been already synthetized in the previous section. Thus, I prefer to use these lines to point out some of the challenges to be faced in the future.

Policy-makers and human rights professionals should explore the dynamic dimension of the UNGP to create innovative mechanisms, like the CLC, which engages and orients public, corporate and civil governance in the same direction. By doing so, it will be possible to narrow the gap between regulation and complex transnational business activities. Emphasis should be put on developing civil governance, for it is essential to shift the power dynamics and improve the situation of workers, consumers and communities. In the case of Mexico, the working group appointed by the Ministry of the Interior to address the issue of business and human rights should also consider the potential of the CLC in drafting the national action plan. ${ }^{141}$

On the other hand, in terms of criminal justice, the implementation of the CLC will be useless if the impunity rate in Mexico continues at around $98 \%{ }^{142}$ Therefore, the criminal policy needs to be comprehensively restructured to diminish impunity and increase remedy for the victims. Not only for the UNGP, but also for the CLC, this is only the end of the beginning.

141 The preliminary documents produced by this working group are available at Secretaría de Gobernación [Ministry of the Interior] (Mexico), wrere.gob.mx/segob/documentos/documentosdel-grupo-de-trabajo-sobre-empresas-y-derechos-humanos.

142 See INEGI [National Institute of Statistics and Geography] (Mexico) Encuesta Nacional de Victimización 2017 [National Survey of Victimization] available at werw.inegi.org.mx/ saladeprensa/boletines/2017/envipe/envipe2017_09.pdf. 